\title{
Is there any role for corticosteroids in GvHD prophylaxis?
}

\author{
Tapani Ruutu \\ Clinical Research Institute, Helsinki University Hospital, Helsinki, Finland \\ Professor Tapani Ruutu, Biomedicum 2 C, \\ E-mail: tapani.ruutu@hus.fi
}

Tukholmankatu 8 C, 00029 HUS, Helsinki, Finland

Citation: Ruutu T. Is there any role for corticosteroids in GvHD prophylaxis? Cell Ther Transplant 2020; 9(1): 8-12.

\section{Summary}

Corticosteroids have an established role as the first-line treatment of graft-versus-host disease (GvHD), but their role in the prophylaxis of GvHD is less clear. At present, corticosteroids are included in the prophylaxis regimens only rarely. Studies of adding corticosteroid to the most widely used prophylactic regimen, cyclosporine A and a short course of methotrexate, have yielded conflicting results, possibly due to differences in the treatment schedule. In our earlier published randomized prospective study, the addition of methylprednisolone (MP) to cyclosporine and methotrexate resulted in a markedly reduced incidence of acute GvHD. No difference was seen in the survival. In long-term follow-up of this study, after a median follow-up of 24.5 years in living patients, we observed a marked late non-relapse mortality among the patients not given prophylactic MP, probably due to higher incidence of chronic GvHD in this study arm. At the end of the follow-up, 55\% of the patients given MP in the prophylaxis were alive, compared with $20 \%$ in the control arm. These findings suggest that the role of corticosteroids in GvHD prophylaxis should be reevaluated.

\section{Keywords}

Graft-versus-host disease, acute, chronic, prophylaxis, corticosteroids, glucocorticoids, favorable effect.

\section{Introduction}

Corticosteroids have an established role in the treatment of graft-versus-host disease (GvHD). Practically all patients who develop clinically significant acute GvHD after hematopoietic stem cell transplantation (HSCT) are primarily treated with corticosteroids, and about half of them show a good response. However, the role of corticosteroids in the prophylaxis of GvHD is much less clear. They have been used in the prophylaxis in combination with a large number of other drugs including cyclosporine A (CsA), tacrolimus, methotrexate (Mtx), mycophenolate mofetil, cyclophosphamide, antilymphocyte globulin, and monoclonal ricin-combined or other antibodies [1]. The proportion of allogeneic HSCT patients given prophylactic corticosteroid has, however, been low. Among the patients reported to the EBMT registry, overall approximately 4 per cent had received corticosteroid prophylaxis, and this proportion has been declining, from about 10 per cent in the 1990s to approximately 2 per cent in the most recent years.

\section{Studies on the addition of corticosteroid to CsA + Mtx}

The combination of cyclosporine and a short course of methotrexate is the most widely used regimen for GvHD prophylaxis [2]. The addition of corticosteroid to this regimen has been studied in a few prospective randomized trials. Storb et al. [3] found that the addition of corticosteroid resulted in an increased incidence of acute GvHD, whereas Atkinson and coworkers [4] did not observe any significant effect. In the study of Hoyt et al. [5] a delayed onset of acute GvHD in the group given the triple prophylaxis was seen, but the incidence remained similar to the control group.

We carried out a prospective randomized comparison of $\mathrm{CsA}+\mathrm{Mtx}+$ methylprednisolone (MP) vs CsA + Mtx in the years 1989-1994 [6]. In this single-center study, 108 consecutive adult allogeneic transplant patients treated for a malignant blood disease were randomized to receive CsA + Mtx with (53 patients) or without MP (55 patients) for GvHD prophylaxis. They received myeloablative conditioning 
based on total body irradiation (68 patients) or busulfan (40 patients) and a non-manipulated bone marrow graft from an HLA-identical sibling donor. The schedule of MP administration is shown in Table 1.

Table 1. Schedule of methylprednisolone administration [6]

\begin{tabular}{|l|l|}
\hline Days after transplantation & Dose $\mathrm{mg} / \mathrm{kg} / \mathrm{day}$ \\
\hline $14-20$ & 0.5 \\
\hline $21-34$ & 1.0 \\
\hline $35-48$ & 0.5 \\
\hline $49-69$ & 0.25 \\
\hline $70-89$ & 0.12 \\
\hline $90-99$ & 0.12 every other day \\
\hline $100-110$ & 0.06 every other day \\
\hline Doses of $0.25 \mathrm{mg} / \mathrm{kg} /$ day or more were divided in 2 parts \\
\hline
\end{tabular}

We saw a markedly and significantly reduced overall incidence of acute GvHD in the MP+ arm (Fig. 1). Also the incidence of grade II-IV acute GvHD was significantly reduced (13\% vs 36\%). There was a non-significant trend towards a lower incidence of chronic GvHD in the MP+ arm. The relapse rates did not differ. There was no significant difference in the survival rates (at 6 years 60 per cent and 51 per cent in the $\mathrm{MP}+$ and MP- arms, respectively). In the $\mathrm{MP}+$ group the neutrophil recovery was faster, there were fewer infections, and the hospitalization time was shorter. The total amount of MP given was similar in the two arms due to markedly higher incidence of acute GvHD in the MP- arm and aggressive GvHD treatment policy.

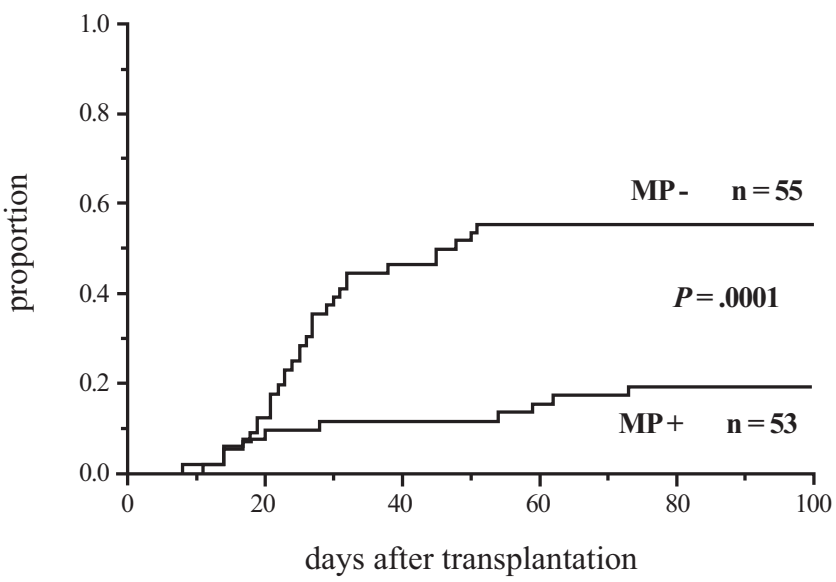

Figure 1. Cumulative incidence of grade I-IV acute GvHD in patients given or not given methylprednisolone (MP) [6]

We performed a long-term follow-up of the patients in our study after a median follow-up of 24.5 (22.7-26.9) years in living patients [1]. The overall survival had remained similar in the study arms until 15 years post-transplantation (Fig. 2). Thereafter the curves deviated; by the end of the follow-up eleven patients had died in the MP- arm more than 15 years after the transplantation, but no patient in the $\mathrm{MP}+$ arm. The mortality was due to non-relapse causes (Fig. 3), there was no difference in the relapse rate. At the end of the follow-up, $55 \%$ of the patients were alive in the $\mathrm{MP}+$ arm, compared with $20 \%$ in the control arm.

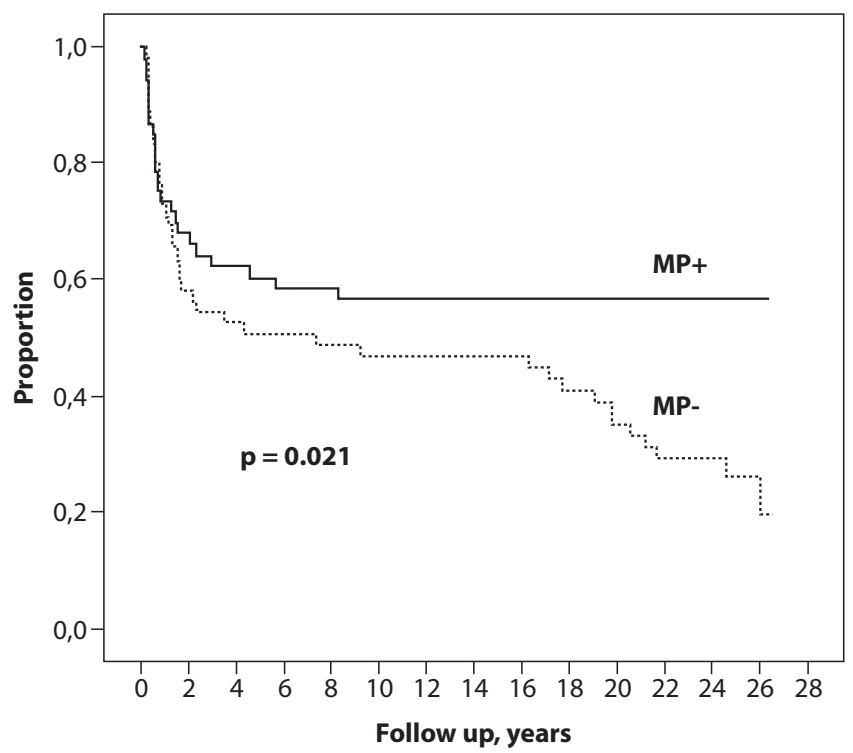

Figure 2. Overall survival of patients given or not given methylprednisolone (MP) [1]

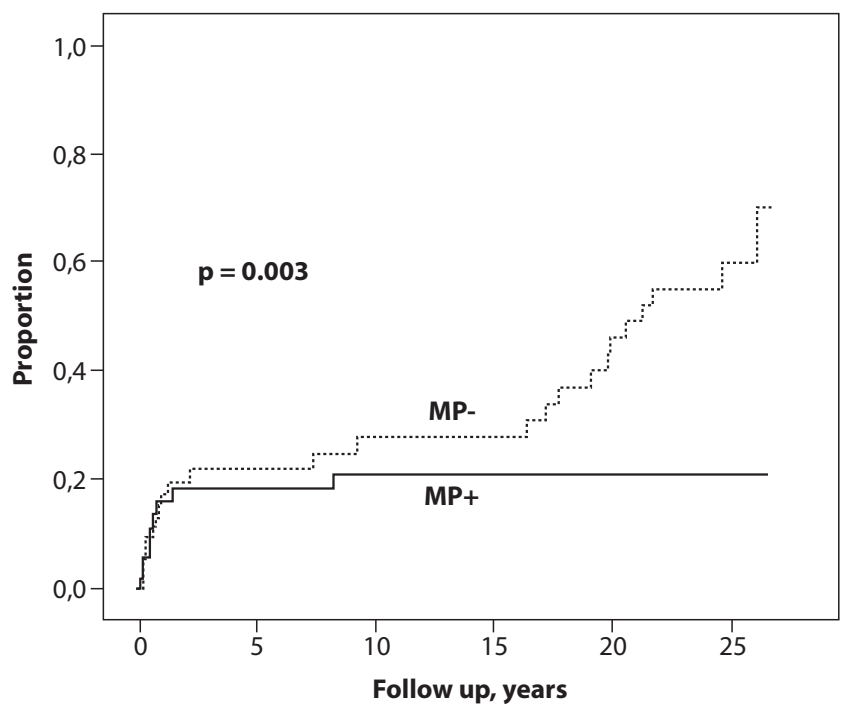

Figure 3. Non-relapse mortality of patients given or not given methylprednisolone [1]

In the patients who died in the MP- group more than 15 years post-transplantation, the causes of death were: bacterial infection in 3 patients, obstructive bronchiolitis in 1 , confirmed or probable cardiovascular cause in 3 , and second cancer in 4 patients.

We had detailed follow-up data of the patients for the first ten years after the transplantation, and during this period the prevalence of chronic GvHD was significantly lower in the $\mathrm{MP}+$ arm (Fig. 4). At ten years, $28 \%$ of the patients in the $\mathrm{MP}$ - group but no one in the MP+ group had active chronic GvHD. Of the eleven patients who had a late death in the MP- arm, nine had had chronic GvHD. Of the remaining two patients, one died suddenly of an obviously cardiovascular cause, the other one of bacterial infection. 
Prevalence of chronic GVHD

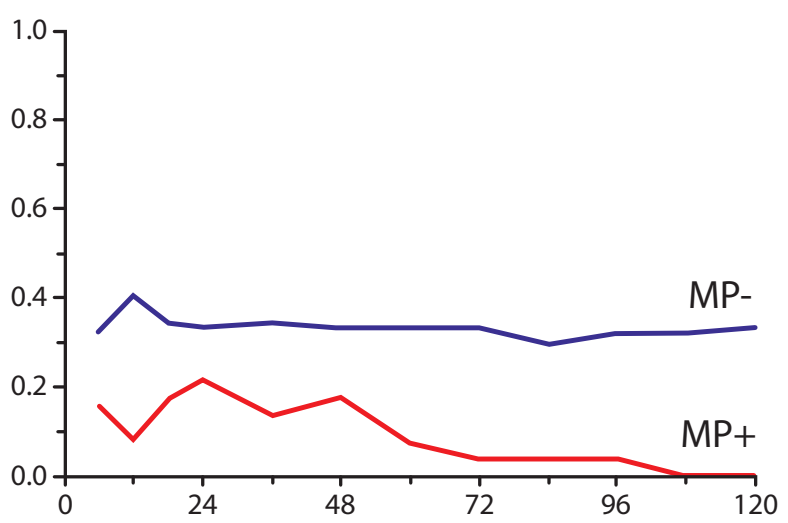

Months

Figure 4. Prevalence of chronic GvHD in patients given or not given methylprednisolone (MP) [1]

\section{Discussion}

The effects of the addition of corticosteroid to CsA + MP for GvHD prophylaxis have been conflicting in short-term reports $[3,4,5,6]$. The reasons remain uncertain, but some possible factors can be identified. An important factor may have been the timing of the corticosteroid administration. In the two studies showing no useful effect of corticosteroid by Storb et al. [3] and Atkinson et al. [4], the administration was initiated at the time of the transplantation and given simultaneously with the other components of the regimen, whereas in the studies of Ruutu et al. [6] and Hoyt et al. [5], corticosteroid was initiated only after the short course of Mtx. It is possible that corticosteroid interfered with the effect of the other prophylactic drugs. In the Seattle study [3] the corticosteroid addition resulted in an increased incidence of acute GvHD, but this effect disappeared if the corticoid treatment was postponed to day 15 and started only after the methotrexate course. Another factor may be the duration of corticosteroid administration. In the studies by Storb et al. [3] and Atkinson et al. [4], corticosteroids were given for only 30-35 days, whereas in our study [6] this treatment was given until day 110 and in that of Hoyt et al. [5] until day 100. A third factor may be differences in the target CsA concentrations applied [6]. It looks likely that the conflicting results of the corticosteroid addition to CsA + Mtx are at least partly due to differences in the treatment schedule.

The cause of the difference between the study groups in non-relapse mortality due to high late mortality in the MPgroup in our long-term follow-up study is not fully obvious, but chronic GvHD is a likely candidate. The prevalence of chronic GvHD was higher during the first ten years after the transplantation in the group of patients not given corticosteroid.

Nine of eleven patients who died more than 15 years after the transplantation had had chronic GvHD. The main causes of death were infection, cardiovascular event and second cancer. Immune deficiency associated with chronic GvHD is a major cause of morbidity and mortality from infections [7]. Chronic GvHD has been shown to be a risk factor for secondary malignancy $[8,9,10]$, and active chronic GvHD is associated with an increased risk of cardiovascular morbidity and mortality $[7,11]$.

The findings of our long-term study would naturally need confirmation from other studies. However, to our knowledge no study on this subject with a follow-up time long enough to cover the time when the late complications took place in our study has been published. Deeg and coworkers [12] published a long-term follow-up of their randomized study where the addition of MP to CsA prophylaxis had been investigated. In the original publication [13] there was significantly less grade II-IV acute GvHD and more chronic GvHD in the MP+ arm, but no difference in the survival. In the long-term follow-up, the median follow-up time was only six years, and no effect of the corticoid addition on the survival was seen. This is in line with our study with the same follow-up.

The prophylactic use of corticosteroid for GvHD is infrequent at present. This reflects the sparsity of documentation to support such use and variable results in the literature. Our study of the addition of corticosteroid to the combination $\mathrm{CsA}+\mathrm{Mtx}$, demonstrating a marked decrease in the incidence of acute GvHD, also showed a beneficial effect on long-term survival, most likely by reducing chronic GvHD and its consequences. These findings suggest that the role of corticosteroids in GvHD prophylaxis should be reevaluated, as also suggested in another transplant setting, haploidentical transplantation $[14,15,16]$.

\section{Conflict of interest}

No conflicts of interest reported.

\section{References}

1. Ruutu T, Nihtinen A, Niittyvuopio R, Juvonen E, Volin L. A randomized study of cyclosporine and methotrexate with or without methylprednisolone for the prevention of graftversus-host disease: Improved long-term survival with triple prophylaxis. Cancer. 2018; 124: 727-733.

2. Penack O, Marchetti M, Ruutu T, Aljurf M, Bacigalupo A, Bonifazi F, Ciceri F, Cornelissen J, Malladi R, Duarte RF, Giebel S, Greinix H, Holler E, Lawitschka A, Mielke S, Mohty M, Arat M, Nagler A, Passweg J, Schoemans H, Socié G, Solano C, Vrhovac R, Zeiser R, Kröger N, Basak GW. Prophylaxis and management of graft-versus-host disease after stem cell transplantation for haematologic malignancies: updated consensus recommendations of the European Society for Blood and Marrow Transplantation. Lancet Haematol. 2020; 7: e157-e167.

3. Storb R, Pepe M, Anasetti C, Appelbaum FR, Beatty P, Doney K, Martin P, Stewart P, Sullivan KM, Witherspoon R, Bensinger W, Buckner CD, Clift R, Hansen J, Longton G, Loughran T, Petersen FB, Singer J, Sanders J, Thomas ED. What role for prednisone in prevention of acute graft-versus-host disease in patients undergoing marrow transplant? Blood. 1990; 76: 1037-1045. 
4. Atkinson K, Biggs J, Concannon A, Dodds A, Young S, Wilson F, Ashby M, Downs K. A prospective randomized trial of cyclosporine and methotrexate versus cyclosporine, methotrexate and prednisolone for prevention of graft-versus-host disease after HLA-identical sibling marrow transplantation for haematological malignancy. Aust NZ J Med. 1991; 21: 850-856.

5. Hoyt R, Ritchie DS, Roberts AW, MacGregor L, Curtis DJ, Szer J, Grigg AP. Cyclosporin, methotrexate and prednisolone for graft-versus-host disease prophylaxis in allogeneic peripheral blood progenitor cell transplants. Bone Marrow Transplant. 2008; 41: 651-658.

6. Ruutu T, Volin L, Parkkali T, Juvonen E, Elonen E. Cyclosporine, methotrexate, and methylprednisolone compared with cyclosporine and methotrexate for the prevention of graft-versus-host disease in bone marrow transplantation from HLA-identical sibling donor: a prospective randomized study. Blood. 2000; 96:2391-2398.

7. Socie G, Ritz J. Current issues in chronic graft-versushost disease. Blood. 2014; 124: 374-384.

8. Rizzo JD, Curtis RE, Socie G, Sobocinski KA, Gilbert E, Landgren O, Travis LB, Travis WD, Flowers MED, Friedman DL, Horowitz MM, Wingard JR, Deeg HJ. Solid cancers after allogeneic hematopoietic cell transplantation. Blood. 2009; 113: $1175-1183$.

9. Majhail NS, Brazauskas R, Rizzo JD, Sobecks RM, Wang Z, Horowitz MM, Bolwell B, Wingard JR, Socie G. Secondary solid cancers after allogeneic hematopoietic cell transplantation using busulfan-cyclophosphamide conditioning. Blood. 2011; 117: 316-322.

10. Shimoni A, Shem-Tov N, Chetrit A, Volchek Y, Tallis E, Avigdor A, Sadetzki S, Yerushalmi R, Nagler A. Secondary malignancies after allogeneic stem-cell transplantation in the era of reduced-intensity conditioning; the incidence is not reduced. Leukemia. 2013; 27: 829-835.

11. Chow EJ, Wong K, Lee SJ, Cushing-Haugen KL, Flowers MED, Friedman DL, Leisenring WL, Martin PJ, Mueller BA, Baker KS. Late cardiovascular complications after hematopoietic cell transplantation. Biol Blood Marrow Transplant. 2014; 20: 794-800.

12. Deeg HJ, Flowers MED, Leisenring W, Appelbaum FR, Martin PJ, Storb RF. Cyclosporine (CSP) or CSP plus methylprednisolone for graft-versus-host-disease prophylaxis in patients with high-risk lymphohemopoietic malignancies: long-term follow-up of a randomized trial. Blood. 2000; 96:1194-1195.

13. Deeg HJ, Lin D, Leisenring W, Boeckh R, Anasetti C, Appelbaum FR, Chauncey TR, Doney K, Flowers M, Martin P, Nash R, Schoch G, Sullivan KM, Witherspoon RP, Storb R. Cyclosporine or cyclosporine plus methylprednisolone for prophylaxis of graft-versus-host disease: a prospective randomized trial. Blood. 1997; 89: 3880-3887.

14. Alyea EP. Graft-versus-host disease prevention: corticosteroids revisited. J Clin Oncol. 2016; 34: 1836-1837.
15. Chang YJ, Xu LP, Wang Y, Zhang XH, Chen H, Chen YH, Wang FR, Han W, Sun YQ, Yan CH, Tang FF, Mo XD, Liu KY, Huang XJ. Controlled, randomized, open-label trial of risk-stratified corticosteroid prevention of acute graft-versus-host disease after haploidentical transplantation. J Clin Oncol. 2016; 34: 1855-1863.

16. Chang YJ, Xu LP, Wang Y, Zhang XH, Chen H, Chen YH, Wang FR, Han W, Sun YQ, Yan CH, Tang FF, Mo XD, Liu KY, Huang XJ. Effect of low-dose glucocorticoid prophylaxis on chronic graft-versus-host disease and graft-versus-host disease-free, relapse-free survival after haploidentical transplantation: long-term follow-up of a controlled, randomized open-label trial. Biol Blood Marrow Transplant. 2019; 25: 529-537. 


\section{| Играют ли роль кортикостероиды в профилактике РТПХ?}

\section{Тапани Рууту}

Институт клинических исследований, Университетский госпиталь Хельсинки, Финляндия

\section{Резюме}

Кортикостероиды играют определенную роль в качестве терапии первой линии реакции «трансплантат против хозяина» (РТПХ), но их значение в профилактике РТПХ менее ясно. В настоящее время кортикостероиды лишь в редких случаях включают в профилактические режимы. Исследования по добавлению кортикостероидов в наиболее широко применяемые режимы профилактики, с циклоспорином А и коротким курсом метотрексата приводили к противоречивым результатам, вероятно - из-за различий в схеме лечения. В нашем ранее опубликованном рандомизированном проспективном исследовании, добавление метилпреднизолона (МП) к циклоспорину и метотрексату вело к значительному снижению частоты острой РТПХ. Не отмечалось различий по выживаемости. При долгосроч- ном обследовании в этом исследовании, после 24,5 лет наблюдения у живущих пациентов мы отмечали существенную позднюю смертность, не связанную с рецидивами, среди пациентов, которые не получали профилактику МП, вероятно - из-за более высокой частоты хронической РТПХ в этой линии исследования. По окончании наблюдения, 55\% пациентов, которым назначали МП для профилактики, были живы, по сравнению с 20\% в контрольной группе. Эти находки предполагают, что роль кортикостероидов в профилактике РТПХТ следует переоценить.

\section{Ключевые слова}

Реакция «трансплантат против хозяина», острая, хроническая, профилактика, кортикостероиды, глюкокортикоиды, благоприятный эффект. 